\title{
ON THE RELATIONSHIP BETWEEN SELECTED SOCIO-ECONOMIC INDICATORS AND STUDENT PERFORMANCES IN THE PISA 2015 STUDY
}

\author{
Jiří Mazurek, Elena Mielcová
}

\section{Introduction}

Knowledge is certainly one of the most important assets possessed both by individuals and by societies. In (substantial) part of the World, knowledge of individuals is obtained via a formal education in an educational system divided into subsequent several stages (usually pre-primary, primary, secondary, and tertiary education). Nowadays, populations' costs of formal public education in the majority of countries constitute a significant portion of national wealth, often exceeding $5 \%$ of a gross domestic product. On average, World's education costs reached $4.7 \%$ of the World's GDP in 2013, according to the World Bank (2017). The costs of private education and especially the costs of tertiary education at the top universities in the USA, Canada, UK, or China are also considerably high.

It is common knowledge that better education pays-off from a point of view of both an individual and society as a whole. Better education improves chances to get a better job, increases competitiveness, and enhances self-realization. However, how efficient are governments' expenses on education for different countries? Do higher expenses on education translate into better knowledge or skills of students? Do students from countries that invest more into public education acquire better education compared to their counterparts from less investing countries?

Recent large international studies, such as PISA (Programme for International Student Assessment) and TIMSS (Trends in International Mathematics and Science Study) of students' skills and knowledge in several areas such as reading, mathematics, or science provide a unique opportunity for international comparisons. Studies on the efficiency of education both at the micro-level, including individual schools and courses, and the macro- level, including countries, regions, or districts, are relatively common, see e.g. Hanushek (1986), Lockheed and Hanushek (1994), Clements (2002), Afonso and Aubyn (2005), Aubyn, Pina, Garcia and Pais (2009), Aristovnik and Obadic (2014), Gavurova, Kocisova, Belas, and Krajcik (2017), or Flores (2017). However, there are not many studies examining a direct link between students' outcomes in standardized tests (such as PISA and TIMSS) and other macroeconomic variables such as GDP per capita, governments' expenditures on education, or teachers' salaries.

Clements (2002) compared selected countries in terms of their expenditure per student and teacher to a student ratio as input variables, and the international standardized test (TIMSS) as an output variable. He concluded that the resources were not used effectively. Herrera and Pang (2005) also compared the efficiency of government spending of 140 countries during the $1996-2002$ period via DEA (Data Envelopment Analysis) and FDH (Free Disposable Hull) methods with nine education output indicators. Their result suggests that developing countries lag behind benchmark Western countries by $10-30 \%$. Similarly, Afonso and Aubyn (2006) used the DEA approach to assess the efficiency of expenditure for 25 countries participating in the PISA 2003 study. Overall, their main finding is that expenditures are highly inefficient. Further, they showed that the GDP per capita and parents' educational attainment are highly and significantly correlated to PISA scores, which means a wealthier and more cultivated environment is important for better student performances.

Akiba, Chiu, Shimizu, and Liang (2006) provided a comparison of countries with respect to PISA performance and teacher salaries. They compared the PISA 2006 scores and teacher salaries for 30 countries with the result that 
countries with higher salaries are more likely to achieve higher scores in PISA. Waldfogel and Thai (2008) studied the link between public preschool expenditures and TIMMS scores $(1995,2003)$ of the fourth graders. Their results indicate there are small but significant positive effects of public preschool expenditures on the mathematics and science scores. Another support of this theory can be found in the work of Carnoy, Beteille, Brodziak, Loyalka, and Luschei (2009). They examined a link between mathematics teacher salaries and mathematics scores in PISA tests. Their findings suggested that students' performance is positively and statistically significantly related to teacher salaries in the case of male teachers but not female teachers.

Wolff (2015) found a positive effect of secondary educational spending on both PISA mathematics and literacy scores (both significant at $p=0.01$ ). In addition, primary school spending was also a significant factor in explaining PISA literacy scores. On the other hand, Flores (2017), who examined efficiency in the education of European countries, where one of the outputs were the PISA 2012 scores, achieved more controversial results. She found that the most efficient countries were Poland, Slovenia, and the Czech Republic. In addition, she determined that the relationship between teachers' salaries and PISA scores, and teaching time and PISA scores, was very low.

Hanushek and Woessmann (2011) provided an extensive study on economic factors of international differences in educational achievements with the use of PISA and TIMSS data. Among others, they found a strong relationship between cognitive skills of tested students and economic growth of their respective countries. Nicoletti and Rabe (2012) found that a rise in the expenditure per pupil of $£ 1,000$ in the UK leads to an increase in the test scores of about $2 \%$ of a standard deviation. This effect was tiny but statistically significant. In addition, Agasisti (2011; 2014) provided an empirical study on a set of 20 European countries during 2006-2009. PISA scores were used as an output, while GDP per capita, unemployment rates, teacher salaries, or Internet use were used as the input variables. Teachers' salaries and the Internet use had a positive impact on students' performance; yet GDP per capita was negatively related to efficiency. Yorulmaz, Colak, and Ekinci (2017) studied the relationship between PISA 2015 scores and income inequality of a respective country. The results suggest that income inequality was one of the variables influencing the PISA achievements of the students, but several countries with high-income inequality scored above average results nonetheless. Gavurova et al. (2017) used the data from the International Monetary Fund (IMF) and the PISA 2015 scores from OECD, and the DEA method to analyze the relative efficiency of government expenditure on secondary education for a set of 31 European countries. The average efficiency was found very high (0.955).

Lorcu and Bolat (2015) used DEA and SEM (Structural Equation Model) to evaluate EU countries plus Turkey. They found that the most effective input variable was the public expenditure on education as a percentage of GDP, and the least effective country was Turkey.

However, not only economic variables influence PISA scores. For example, Brunello and Rocco (2013) used PISA scores to study the effect of migration on school performances at the national level. French, French, and $\mathrm{Li}$ (2015) examined a relationship between cultural dimensions (such as power index, masculinity, individualism, etc.) and public expenditure on education, and the national PISA 2000-2012 scores. They found a strong positive association between public spending on education and PISA scores. In addition, individualism and long-term orientation had a positive impact on PISA scores.

Rinderman and Ceci (2009) tried to find the link between PISA scores and pre-test activities of students. They used PISA $(2003,2006)$ studies results to document several positive predictors of international differences in student competencies, which included the amount of preschool education, student discipline, the quantity of education, school attendance, or high-stakes tests. Similarly, Sutherland (2009) examined school efficiency at both the national and school level with respect to the PISA 2003 results. They found that holding school resources constant while improving school practice to the level of best schools nationally, could provide a boost by an average of $5 \%$ for OECD countries and by around $10 \%$ for the least efficient countries. The report of McKinsey\&Company (2010) addressed stagnating or decreasing PISA results of 
Czech pupils in PISA 2000-2006 tests. The report noted that though there are examples of significant improvements in PISA scores in several countries (Finland, Hong-Kong), there is no ideal educational model at a national level, and the improvement of the educational results of Czech pupils can be achieved mainly by a transformation from above, beginning at the level of school managing directors, supported by changes in perception of the teacher profession, cooperation with parents and local communities, and also higher expenditures on education in general.

The aim of this paper is to examine the relationship between the PISA international study results from 2015 and a set of socioeconomic indicators (on the national level), such as governments' expenditures on primary education (both relative and absolute expenditures are considered), gross domestic product per capita, teachers' salaries and countries' democracy index, as well as to find out which factors contributed to the higher scores and thus better results, in the latest PISA 2015 research study.

The approach of the presented study is novel in several important ways:

i. We divide the set of all 71 countries into natural subgroups to obtain stronger (more statistically significant) results;

ii. We use methods not previously applied in this field, namely non-linear models based on Törnquist functions, and also cluster analysis;

iii. We use the data that are directly associated to the PISA 2015 results, that is the relevant data for primary education, as students tested in the PISA 2015 were 15 or 16 years old (just one or two years after the end of their primary education). Many other similar studies use data for the whole educational sector or tertiary education which are not relevant to the PISA study;

iv. And at last, but not least, we take advantage of the data (variables) never used before.

It is also worth noting that our dataset of 71 examined countries is much larger than datasets in previous studies, which mainly focused solely on OECD or European countries.

The data for our analysis were gathered mostly from OECD and the World Bank databases, and the applied models include Törnquist functions, linear (multivariate) regression models, and cluster analysis (k-means clustering).
The paper is organized as follows: in section 1, the PISA study is briefly described; in section 2, data and method are described; in section 3 and 4 , the results are provided and discussed. The paper is concluded by section Conclusions.

\section{Programme for International Student Assessment (PISA)}

PISA is a world-wide study of 15-16 old pupils' performance in three areas, mathematics, science and reading, organized by the Organization for Economic Cooperation and Development (OECD).

The first PISA study was conducted in 2000 , and after 2000 it was repeated every 3 years. The last study took place in 2015, the results of the study were published in December 2016, see PISA 2015 - Results in Focus (2016). Altogether, 71 countries or territories participated in the PISA 2015 study: 37 countries from Europe, 19 from Asia, 11 from Americas, 2 from Africa and 2 from Australia and Oceania. The study also included one Buenos Aires district in Argentina, but due to its nonrepresentative nature for the whole country, Argentina was omitted from the presented study.

At least 5,000 pupils were tested in each country. In less populated countries, such as Luxembourg, the entire age cohort was selected. In total, around 540,000 students world-wide participated in the tests. The tests were computer-based with multiple-choice or open answers, and each student's assessment lasted for two hours in total. More details on the methodology of pupils' sampling, the exact formulation of test questions and other features of PISA 2015 can be found in PISA 2015 Results in Focus (2016).

\section{Data Description}

Since pupils tested in PISA 2015 were at the age of 15 or 16 at the time of testing, and assuming they started their primary education at an age of 6 , national economic data were gathered from a period 2006-2015 covering a 10-year interval of mainly primary education of tested pupils prior to the PISA 2015 test.

Description of the data used in this study is provided in Tab. 1. The PISA 2015 country scores is an explained (dependent) variable. Explanatory (independent) variables include GDP per capita, government expenditures 


\begin{tabular}{l|c|c|c}
\multicolumn{1}{c|}{ Variable } & $\begin{array}{c}\text { Number of } \\
\text { observations }\end{array}$ & Abbreviation & Data source \\
\hline $\begin{array}{l}\text { PISA 2015 results as an average of test } \\
\text { scores in three areas: mathematics, } \\
\text { science, and reading }\end{array}$ & 71 & $\begin{array}{c}\text { PISA (MATH, } \\
\text { SCIENCE, READ } \\
\text { for its respective } \\
\text { parts) }\end{array}$ & $\begin{array}{c}\text { PISA 2015 - } \\
\text { Results in Focus } \\
\text { (2016) }\end{array}$ \\
\hline $\begin{array}{l}\text { Gross domestic product per capita (in } \\
\text { USD), averaged over 2006-2015 }\end{array}$ & 70 & GDP & WorldBank (2017) \\
\hline $\begin{array}{l}\text { Government expenditure on primary } \\
\text { education per student (government } \\
\text { expenditure per student is the average } \\
\text { general government expenditure, current, } \\
\text { capital, and transfers, per student in the } \\
\text { given level of education, expressed as a } \\
\text { percentage of GDP per capita), averaged } \\
\text { over 2006-2015 }\end{array}$ & 56 & PEREXP & WorldBank (2017) \\
\hline $\begin{array}{l}\text { Government expenditures on primary } \\
\text { education per capita in USD averaged } \\
\text { over 2006-2015 }\end{array}$ & 56 & EXPEND & WorldBank (2017) \\
\hline $\begin{array}{l}\text { The Democracy index from 2015 } \\
\begin{array}{l}\text { Primary teachers' salaries from 2014 } \\
\text { (teachers with a 10-year practice) }\end{array}\end{array}$ & $\begin{array}{c}\text { 32 (OECD } \\
\text { countries only) }\end{array}$ & SALARY & $\begin{array}{l}\text { Education at a } \\
\text { Glance (2016) }\end{array}$ \\
\hline
\end{tabular}

on primary education per capita, both relative (in \%) and absolute (in annual USD), primary teachers' salaries (in annual USD) and the Democracy index.

Four out of five independent variables (GDP, PEREX, EXPEND, SALARY) are economic variables directly relevant to the merit of this study and applied in many previous studies on the economic efficiency of education. The fifth indicator, the Democracy index (DEM), was included into our study because of three reasons: firstly, it is a complex index compiled by the Economics Intelligence Unit (EIU) consisting of 60 basic indicators divided into five areas: electoral process and pluralism, civil liberties, functioning of government, political participation, and political culture; hence it reflects a cultural and political climate of a given country, which in turn might have a substantial effect on education outcomes, see also Hanushek and Woessmann (2010) or French et al. (2015). Secondly, the Democracy index has never been used before (according to our knowledge) in a similar research, which might lead to new insights into the problem. At last, but not least, the data for the Democracy index were available for all the countries participating in the PISA 2015 study, so no country had to be omitted due to the missing data. Since DEM was released by EIU rather irregularly, it was not averaged over 2006-2015. Instead, the DEM values from the year when PISA tests were conducted were used for this study (annual changes of DEM are rather negligible as the year-to-year changes of national political and cultural environment are usually very small).

Regrettably, not all data for all countries were available; therefore, we considered various specifications of linear regression models by adding or removing variables.

Tab. 2 provides average values of all examined variables along with their standard deviations. A linear relationship between pairs of variables in a form of a correlation matrix is shown in Tab. 3. Results of correlation analysis indicate PISA 2015 scores tests are positively and statistically significantly correlated with all independent variables with the exception of teachers' salaries (which were available only for OECD countries). 
Tab. 2: Descriptive statistics of main variables

\begin{tabular}{l|r|r|r} 
& \multicolumn{1}{|c|}{ Mean } & \multicolumn{1}{|c}{ Standard deviation } & N \\
\hline PISA & 462.490 & 51.37 & 71 \\
\hline GDP & $26,587.540$ & $23,421.17$ & 70 \\
\hline PEREXP & 18.950 & 5.83 & 56 \\
\hline EXPEND & $5,651.960$ & $5,039.64$ & 56 \\
\hline DEM & 7.090 & 1.75 & 67 \\
\hline SALARIES & $38,550.781$ & $16,344.53$ & 32 \\
\hline
\end{tabular}

Source: own

Tab. 3: Pairwise Pearson's correlations of main variables

\begin{tabular}{l|c|c|c|c|c|c} 
& PISA & GDP & PEREXP & EXPEND & DEM & SALARIES \\
\hline PISA & - & $0.566^{* *}$ & $0.336^{*}$ & $0.562^{* *}$ & $0.515^{\star *}$ & 0.432 \\
\hline GDP & & - & 0.131 & $0.945^{\star *}$ & $0.512^{* *}$ & $0.832^{* *}$ \\
\hline PEREXP & & & - & $0.342^{* *}$ & $0.320^{*}$ & $0.216^{*}$ \\
\hline EXPEND & & & & - & $0.652^{* *}$ & $0.839^{* *}$ \\
\hline DEM & & & & & - & $0.617^{* *}$ \\
\hline SALARIES & & & & & & - \\
\hline
\end{tabular}

Source: own

Note: * statistically significant at 0.10 level, ${ }^{* *}$ at 0.05 level, ${ }^{* *}$ at 0.01 level.

\section{Results}

We use three different statistical tools to examine the relationship between PISA scores and other selected variables. Multivariate linear models provide insights into (linear) relations between selected independent variables and PISA 2015 scores. One-toone nonlinear Törnquist function models can reveal another feature of PISA scores - a saturation level of PISA scores with respect to a given independent variable. As to our best knowledge, this approach has not been applied before. Finally, cluster analysis can distinguish groups of countries (or territories) with similar features that can be used for a subsequent and more detailed analysis.

\subsection{Multivariate Linear Regression Models}

In general, multivariate linear regression models take the following form:

$$
y_{i}=\beta_{0}+\beta_{1} x_{1 i}+\ldots+\beta_{p} x_{p i}+\varepsilon_{i}
$$

where $\mathrm{y}$ denotes the dependent (explained) variable, $x=\left(x_{1}, \ldots, x_{p}\right)$ is a vector of $p$ independent (explanatory) variables, $i$ denotes individual countries and $\varepsilon$ is the error term. If all assumptions for its use are satisfied, the ordinary least squares method is the best linear unbiased estimator. Otherwise, other estimation methods, such as generalized least squares, nonlinear least squares, or maximum likelihood estimation, have to be implemented (Kmenta, 1986).

The relationship between GDP and PISA variables, as well as the relationship between EXPEND and PISA variables, is shown in Fig. 1. Even though the relationship seems to be nonlinear, Pearson's $\rho$ for the linear relationship of PISA scores on both variables is rather high, 0.565 , and 0.562 for GDP and EXPEND values 


\section{Fig. 1: Dependence of PISA scores on GDP values and EXPEND values}
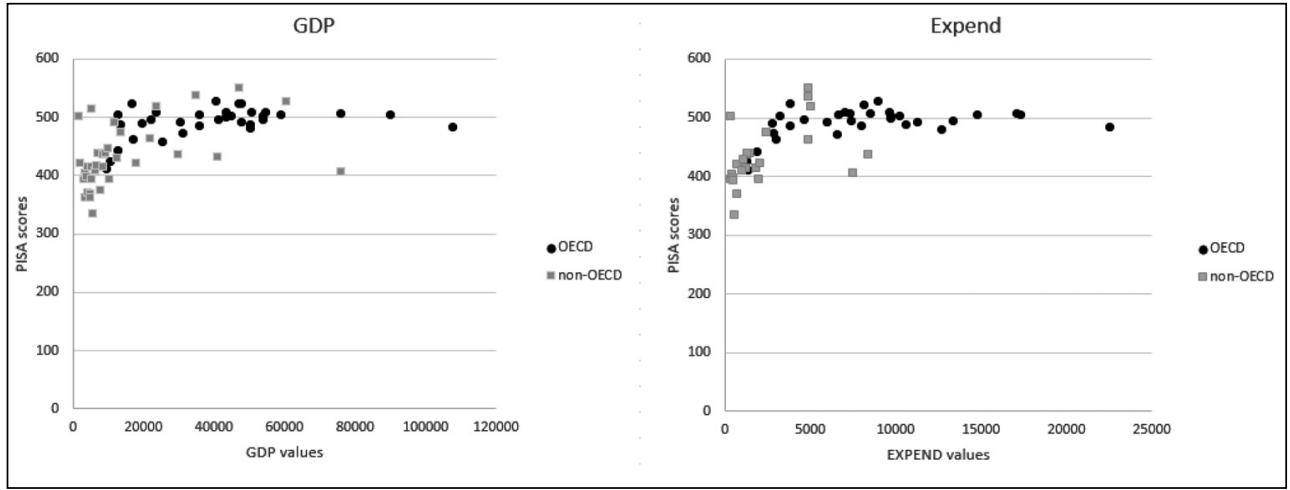

Source: own

respectively. The interesting point is that when data are divided into OECD (black dots in Fig. 1) and non-OECD countries (gray squares in Fig. 1), the linear relation between PISA and GDP (or EXPEND) variables is different, hence, this fact should be taken into account in the model selection and specification.

The relationship between DEM and PISA variables, and SALARY and PISA variables are shown in Fig. 2.

Similarly as in the case of the GDP and EXPEND influence on PISA, the DEM variable has a significantly positive linear relationship with PISA even though it is smaller when compared to GDP and EXPEND ( $\rho=0.515)$. In addition, in this case, data can be divided into OECD (black dots) and non-OECD countries (gray squares), and the linear relation between PISA and DEM is different for OECD and non-OECD countries. Unfortunately, data for SALARY were available mostly for OECD countries; hence, this variable could not be included in all models. Moreover, the correlation coefficient of this variable is not statistically significant.

For the multivariable linear regression model, we use the following particular form of the general equation (1) and models derived from this basic form:

\section{Fig. 2: Dependence of PISA scores on DEM values and SALARY values}

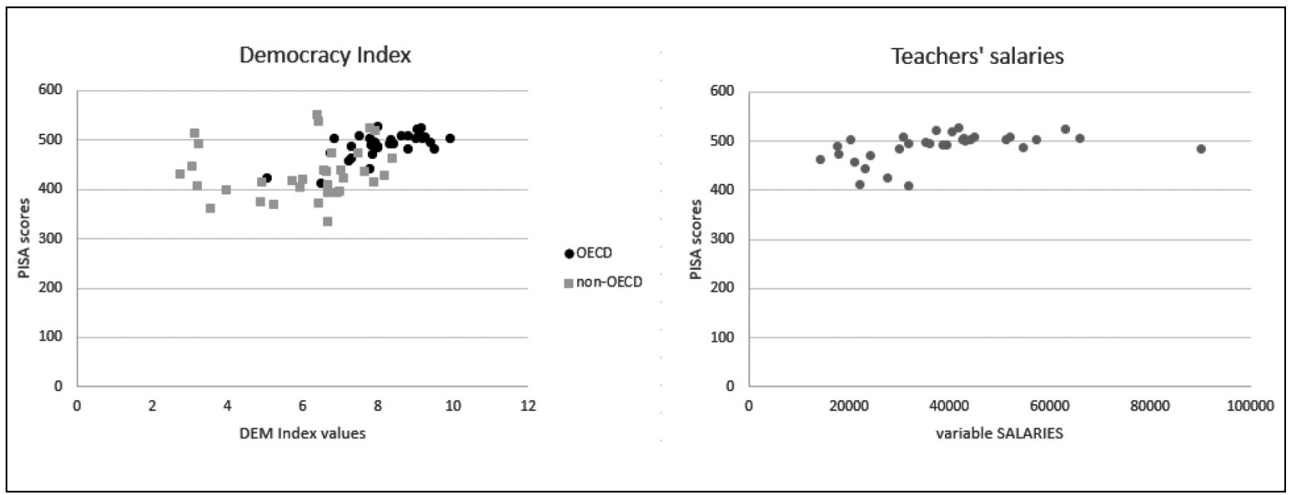




$$
\begin{aligned}
& \text { PISA }_{i}=\beta_{0}+\beta_{1} \text { GDP }_{i}+\beta_{2} \text { PEREXP }_{i}+ \\
& +\beta_{3} \text { EXPEND }_{i}+\beta_{4} D E M_{i}+\beta_{5} \text { SALARY }_{i}+\varepsilon_{i}
\end{aligned}
$$

The estimation was performed via statistical software Gretl. Because of the heteroscedasticity of the dataset, the OLS method with corrected heteroscedasticity, which is a built-in feature in Gretl, was used for the estimation.

The result of estimation of the model (2) is provided in Tab. 4, labeled as Model 1. According to $R^{2}$, almost $75 \%$ of the variability in data can be described by this model; almost all regression coefficients are statistically significant with the only one exception - the SALARY variable. The problematic point is, that the relation between PISA and EXPEND is negative. This is rather counterintuitive and may indicate a multicollinearity problem. In our case, the multicollinearity problem could be caused by a high correlation of GDP per capita with governmental expenditures on primary education per capita $(\rho=0.945)$, and teachers' salaries variable $(\rho=0.832)$ as indicated in a correlation matrix given in Tab. 3. Hence, we decided to estimate additional models. While Model 1 features all independent variables, in Model 2 the SALARY variable is omitted:

$$
\begin{aligned}
& P_{S I S A_{i}}=\beta_{0}+\beta_{1} G D P_{i}+\beta_{2} P E R E X P_{i}+ \\
& +\beta_{3} E X P E N D_{i}+\beta_{4} D E M_{i}+\varepsilon_{i}
\end{aligned}
$$

The next Model 3 features GDP, PEREXP and DEM only:

$$
\begin{aligned}
& \text { PISA }_{i}=\beta_{0}+\beta_{1} G D P_{i}+\beta_{2} \text { PEREXP }_{i}+ \\
& +\beta_{4} D E M_{i}+\varepsilon_{i} .
\end{aligned}
$$

Results of these estimations are given in Tab. 4. While in Model 2 all regression coefficients were statistically significant, in the case of Model 3 the PEREX variable is not statistically significant. With a decreasing number of variables, the coefficient of determination decreases, as well, it decreased from 0.741 in Model 1 to 0.383 in Model 4, including only GDP and DEM variables:

$$
P I S A_{i}=\beta_{0}+\beta_{1} G D P_{i}+\beta_{4} D E M_{i}+\varepsilon_{i} .
$$

Models 1-4 were re-estimated for the case of OECD countries. In Model 5 (equivalent to Model 1) all variables but salaries were statistically significant. As in previous estimations, in Models 5 and 6 the sign of the EXPEND variable was negative. The interesting point is that after eliminating the EXPEND variable from the estimation (Models 7 and 8 ), the GDP variable is not statistically significant. This tendency is visible also in Fig. 1, where in the case of OECD countries the values of PISA scores are almost constant for all values of GDP. The last estimated model based on the data from OECD countries only is Model 9, which takes the following form:

$$
\text { PISA }_{i}=\beta_{0}+\beta_{2} \text { PEREXP }_{i}+\beta_{4} \text { DEM }_{i}+\varepsilon_{i} .
$$

The coefficient of determination of this model is 0.476 , which is better than in Model 8 , moreover, both regression coefficients of independent variables are statistically significant.

Models given in Equations (3-6) were reestimated for data from non-OECD countries. Results of these estimations are given in Tab. 4 as Models 10-13. Model estimations in the case of non-OECD countries give different results when compared to OECD countries' data. The GDP variable is always statistically significant, while values of the coefficient of determination are lower than for models with the data from OECD countries.

Linear models partially describe variability in data. However, the graphs in Fig. 1 indicate, that there is something like a "saturated level" of PISA scores. This kind of relationship can be better described by a non-linear function as shown in the next section.

\subsection{Models Based on the Törnquist Function}

As mentioned above, data shown in Fig. 1 indicate, that up to GDP per capita equal to approximately 20,000 USD the relationship between PISA scores and levels of GDP is close to a linear dependence. Then, for GDP per capita exceeding approximately 20,000 USD per capita, this relationship levels off. In other words, for the poorest countries with the lowest GDP per capita the relationship "the higher is GDP per capita, the higher is PISA score" applies more than for wealthy countries. For countries with the GDP per capita exceeding 20,000 USD, this direct proportion is clearly invalid. The same is the situation in the case of the EXPEND variable; for government expenditures on primary education per capita in 


\section{Tab. 4: Results of multivariable linear regression models}

\begin{tabular}{|c|c|c|c|c|c|c|c|c|}
\hline Model & Sample size & $\mathbf{R}^{2}$ & Const. & GDP & PEREXP & EXPEND & DEM & SALARY \\
\hline 1 & 30 & 0.741 & $\begin{array}{c}220.112^{\star * *} \\
(39.9168)\end{array}$ & $\begin{array}{l}0.0034^{* * *} \\
(0.0011)\end{array}$ & $\begin{array}{l}7.7586^{\star \star *} \\
(1.5611)\end{array}$ & $\begin{array}{l}-0.0176^{* * *} \\
(0.0050)\end{array}$ & $\begin{array}{l}13.8602^{* *} \\
(5.0290)\end{array}$ & $\begin{array}{c}0.0002 \\
(0.0004)\end{array}$ \\
\hline 2 & 55 & 0.524 & $\begin{array}{l}253.178^{* * *} \\
(42.1320)\end{array}$ & $\begin{array}{l}0.0026^{* * *} \\
(0.0008)\end{array}$ & $\begin{array}{l}3.1195^{* * *} \\
(1.1067)\end{array}$ & $\begin{array}{l}-0.0105^{* *} \\
(0.0045)\end{array}$ & $\begin{array}{l}18.4568^{* * *} \\
(5.0172)\end{array}$ & - \\
\hline 3 & 55 & 0.473 & $\begin{array}{c}324.469^{\star * *} \\
(30.0826)\end{array}$ & $\begin{array}{l}0.0007^{\star * *} \\
(0.0002)\end{array}$ & $\begin{array}{c}1.4586 \\
(0.8803)\end{array}$ & - & $\begin{array}{l}12.3196^{* * *} \\
(4.4452)\end{array}$ & - \\
\hline 4 & 66 & 0.383 & $\begin{array}{c}376.441^{\star * *} \\
(21.2021)\end{array}$ & $\begin{array}{l}0.0009^{\star \star *} \\
(0.0002)\end{array}$ & - & - & $\begin{array}{l}8.7956^{\star * *} \\
(0.0094)\end{array}$ & - \\
\hline 5 & $\begin{array}{c}28 \\
(O E C D)\end{array}$ & 0.740 & $\begin{array}{c}242.681^{* * *} \\
(36.8094)\end{array}$ & $\begin{array}{l}0.0029^{\star * \star} \\
(0.0010)\end{array}$ & $\begin{array}{l}6.7651^{* * *} \\
(1.4418)\end{array}$ & $\begin{array}{l}-0.0153^{\star * *} \\
(0.0046)\end{array}$ & $\begin{array}{l}13.5345^{\star \star *} \\
(4.5377)\end{array}$ & $\begin{array}{c}0.0003 \\
(0.0004)\end{array}$ \\
\hline 6 & $\begin{array}{c}32 \\
(\mathrm{OECD})\end{array}$ & 0.645 & $\begin{array}{c}265.857^{\star * *} \\
(36.0853)\end{array}$ & $\begin{array}{l}0.0031^{\star * *} \\
(0.0009)\end{array}$ & $\begin{array}{l}6.0890^{\star \star *} \\
(1.3512)\end{array}$ & $\begin{array}{l}-0.0153^{\star \star *} \\
(0.0043)\end{array}$ & $\begin{array}{l}12.6304^{* *} \\
(4.5698)\end{array}$ & - \\
\hline 7 & $\begin{array}{c}32 \\
\text { (OECD) }\end{array}$ & 0.482 & $\begin{array}{c}323.721^{* * *} \\
(38.1346)\end{array}$ & $\begin{array}{l}-0.0001 \\
(0.0002)\end{array}$ & $\begin{array}{l}2.1007^{\star *} \\
(0.8767)\end{array}$ & - & $\begin{array}{l}15.8770^{* \star *} \\
(5.3115)\end{array}$ & - \\
\hline 8 & $\begin{array}{c}34 \\
\text { (OECD) }\end{array}$ & 0.410 & $\begin{array}{c}340.118^{* \star *} \\
(37.7854) \\
\end{array}$ & $\begin{array}{l}-0.0002 \\
(0.0002) \\
\end{array}$ & - & - & $\begin{array}{l}19.3794^{* \star \star} \\
(5.4290)\end{array}$ & - \\
\hline 9 & $\begin{array}{c}32 \\
(\mathrm{OECD})\end{array}$ & 0.476 & $\begin{array}{l}336.432^{* * *} \\
(30.4447)\end{array}$ & - & $\begin{array}{c}2.1247^{\star *} \\
(0.8654)\end{array}$ & - & $\begin{array}{l}13.6289^{* \star *} \\
(3.4814)\end{array}$ & - \\
\hline 10 & $\begin{array}{c}23 \\
\text { (non-OECD) }\end{array}$ & 0.396 & $\begin{array}{c}270.947^{* * *} \\
(76.4066)\end{array}$ & $\begin{array}{c}0.0020 \\
(0.0016)\end{array}$ & $\begin{array}{c}1.1428 \\
(1.7101)\end{array}$ & $\begin{array}{l}-0.0020 \\
(0.0114)\end{array}$ & $\begin{array}{l}17.3544^{*} \\
(9.5142)\end{array}$ & - \\
\hline 11 & $\begin{array}{c}23 \\
\text { (non-OECD) }\end{array}$ & 0.395 & $\begin{array}{c}279.685^{\star * *} \\
(56.5770)\end{array}$ & $\begin{array}{l}0.0018^{\star \star *} \\
(0.0005)\end{array}$ & $\begin{array}{c}0.9509 \\
(0.9509)\end{array}$ & - & $\begin{array}{l}16.6784^{* *} \\
(7.6784)\end{array}$ & - \\
\hline 12 & $\begin{array}{c}32 \\
\text { (non-OECD) }\end{array}$ & 0.169 & $\begin{array}{c}387.349^{* * *} \\
(34.5172)\end{array}$ & $\begin{array}{l}0.0013^{* *} \\
(0.0006)\end{array}$ & - & - & $\begin{array}{c}4.2512 \\
(5.2759)\end{array}$ & - \\
\hline 13 & $\begin{array}{c}23 \\
\text { (non-OECD) }\end{array}$ & 0.064 & $\begin{array}{l}360.906^{\star * *} \\
(61.4068)\end{array}$ & - & $\begin{array}{c}0.3266 \\
(1.5376)\end{array}$ & - & $\begin{array}{c}9.8395 \\
(8.9733)\end{array}$ & - \\
\hline
\end{tabular}

Source: own

Note: * statistically significant at 0.10 level, ${ }^{* *}$ at 0.05 level, ${ }^{* *}$ at 0.01 level.

USD exceeding approximately 5,000 USD per capita, the increase in PISA scores is replaced by an approximately constant level of PISA scores without any influence of the EXPEND variable. One of the possible tools on how to find the saturation level is to use a Törnquist growth function.

The nonlinear $1^{\text {st }}$ type Törnquist growth function is given as follows:

$$
y=\frac{\alpha x}{\beta+x} .
$$

The function (7) is a one-variable model with the nonlinear trend and diminishing marginal values. Both estimated coefficients $\alpha$ and $\beta$ are assumed to be positive. The limit of the function (7):

$$
\lim _{x \rightarrow+\infty} \frac{\alpha x}{\beta+x}=\alpha
$$

determines the natural (saturated) level of a dependent variable $y$ (the asymptote $y=\alpha$ ).

We used the Törnquist function (7) for the evaluation of a potential "saturation" effect of a selected independent variable (GDP or EXPEND) on the PISA variable. The model of the dependence of PISA on the GDP variable (Model 14) is of the form: 


$$
P I S A_{i}=\frac{\alpha \cdot G D P_{i}}{\beta+G D P_{i}}+\varepsilon_{i},
$$

where $\mathrm{i} \in\{1,2, \ldots, 71\}$ in (9) denotes individual countries and the term $\varepsilon$ is the error term.

Results of estimation, performed in Gretl, are provided in Tab. 5; for the purposes of regression, one outlier observation was eliminated from the dataset (Qatar). The coefficient of determination $R^{2}$ is 0.337 , which is a lower value than values obtained by multivariate linear models. However, this approach allows to determine the limit (saturation) level of the PISA value, which is equal to the estimated $\alpha$ level, in our case equal to 495.272 ; the $95 \%$ confidence interval for the coefficient $\alpha$ is [476.683, 513.862]. The respective value of the (saturation) GDP variable (respective to $95 \%$ lower limit of the PISA variable) is $19,367.45$; this value reflects the pattern observed in Fig. 1.

\section{Tab. 5: Results of nonlinear regression of the Törnquist function}

\begin{tabular}{c|c} 
Model 14 & Coefficient (std. error) \\
\hline $\boldsymbol{\alpha}$ & $495.272(53.18)^{\star * *}$ \\
\hline $\boldsymbol{\beta}$ & $755.264(2.670)^{\star * *}$ \\
\hline Model 15 & Coefficient (std. error) \\
\hline $\boldsymbol{\alpha}$ & $496.504(7.135)^{\star \star *}$ \\
\hline $\boldsymbol{\beta}$ & $115.003(38.826)^{\star \star *}$ \\
\hline
\end{tabular}

Source: own

Note: * statistically significant at 0.10 level, ${ }^{* *}$ at 0.05 level, ${ }^{* * *}$ at 0.01 level.

By analogy, the model of nonlinear dependence of PISA on EXPEND has the following form:

$$
P I S A_{i}=\frac{\alpha \cdot E X P E N D_{i}}{\beta+E_{P P E N D}}+\varepsilon_{i},
$$

where the subscript $i$ denotes countries and the term $\varepsilon$ in (5) is the error term. Estimation results are given in Tab. 5. Again, one outlier (Qatar) was eliminated. The coefficient of determination $R^{2}$ is 0.434 , which is slightly higher when compared to the previous model. The limit (saturation) level of the PISA value for this model is 496.504 ; the $95 \%$ confidence interval for the coefficient $\alpha$ is [482.193, 510.814]. This result is close to the interval from the previous model. The respective (saturation) value of the EXPEND variable (respective to the $95 \%$ lower limit of the PISA variable) is 3,874.19.

For the rest of independent variables (PEREXP, DEM, and SALARY), models based on the Törnquist function (7) were not statistically significant, hence, for these variables, the "saturation effect" did not occur.

\subsection{Cluster Analysis}

In the previous sections, we showed that results for OECD and non-OECD countries substantially differ, and stronger (more statistically significant) conclusions might be obtained when the dataset of all 71 countries is divided into subgroups. Therefore, we applied the cluster analysis to find out whether the division between OECD and non-OECD countries (or some other division) will appear. Since cluster analysis groups together similar data points, it enables to reveal common characteristics or features of countries with high PISA 2015 scores, and vice versa.

For clustering, a k-means clustering method via SPSS was employed (see Kanungo (2002) for further explanation of the method). The number of clusters and the number of selected variables for the clustering, along with the complete results, are provided in Appendix A.

In the case of two clusters and all variables with the exception of teacher salaries, which 
were available only for OECD countries, the sample of countries splits into two groups (clusters), see column (2) in AppendixA. The first cluster of countries consisted mainly of OECD countries (27) accompanied by 5 non-OECD, but rather wealthy countries (Cyprus, HongKong, Malta, Singapore and South Korea). The second cluster included mainly non-OECD countries (17) along with 6 OECD countries (Hungary, Chile, Lithuania, Mexico, Slovakia, and Turkey). The null hypothesis, that division of those countries into two clusters does not dependent on their OECD membership, could be rejected by a chi-square test at 0.01 level. Thus, the division between OECD and nonOECD countries was statistically confirmed.

To examine common characteristics of countries with high PISA scores, and vice versa, the sample of countries was divided into three and four clusters, which were the optimal number of clusters according to the k-means clustering method. The countries division is shown in the columns (3-5).
Of all examined models, the most interesting was Model 3. Countries were divided into three groups, see Fig. 3 and Appendix A. Countries in the group 1, mainly developing countries, achieved medium PISA scores, and their values of GDP, EXPEND and DEM variables were also medium, while PEREXP was high. Countries in the group 2, mainly developed and wealthy European states, achieved high PISA scores, and typically featured high values of GDP, EXPEND and DEM variables, but only medium values of PEREXP. Finally, countries in the group 3, mainly developing ones (with the exception of the Czech Republic and Slovakia), were characterized by low values of all variables including PISA scores.

In the case of 4 clusters, see Model 2 in Appendix A, the pattern of the countries division was similar: cluster 1 is mainly occupied by non-European developing countries, cluster 2 consists of exclusively rich Western European countries accompanied by the USA, New Zealand and Japan, in cluster 3 mainly Central

\section{Fig. 3: Clusters in Model 3}

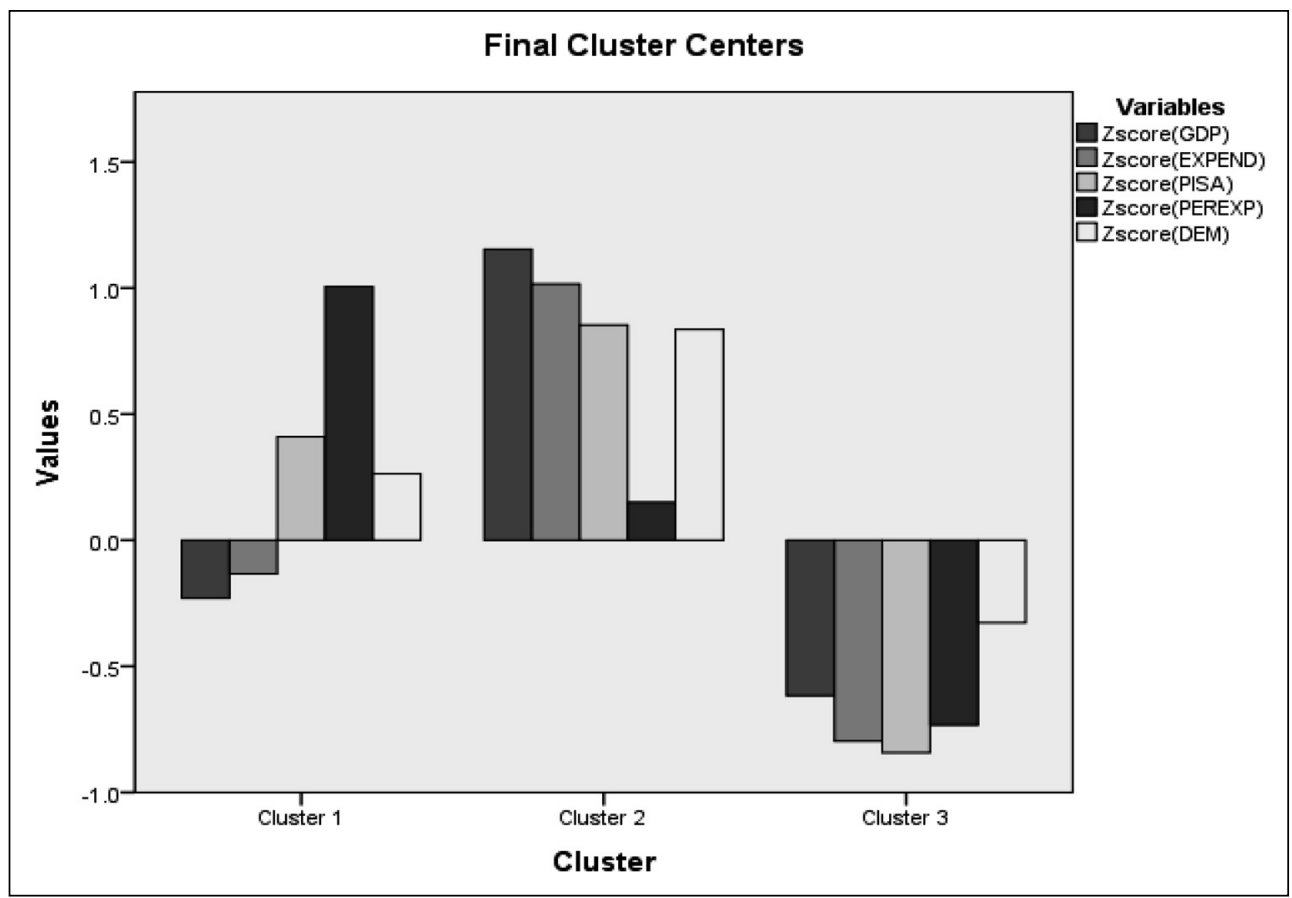


and Eastern European countries are grouped together along with several economically strong Asian countries (Korea, Singapore, China, Hong-Kong). The last cluster 4 includes a mix of moderately wealthy European, American and Asian countries.

\section{Conclusions}

The aim of the paper was to examine the relationships between the national PISA 2015 scores (a dependent variable) for 71 countries worldwide, and a set of socio-economic (independent) variables including countries' GDP per capita, governments' expenditures on primary education, the Democracy index, or teacher salaries.

The main finding of the study is that there is a saturation effect in terms of GDP per capita and government expenditures on primary education per capita (in USD) for wealthy (OECD) countries: an increase in both variables did not translate into an increase in PISA scores after reaching a certain saturation level. In the case of GDP per capita, the saturation level was found around USD 19,000 (in the 2016 prices) and in the case of government expenditures per capita, the saturation level was about USD 3,900 (in the 2016 prices); in both cases, these values correspond to the PISA score levels of approximately 495 . This effect was highly statistically significant (at 0.01 level) and bears strong policy-making implications. Above the aforementioned threshold, a mere increase of financial flows into primary education does not improve student performances in PISA tests. However, below the threshold, which is the case for the majority of developing non-OECD countries, student performance grows with the flow of money into primary education.

The relationship between PISA scores and the set of explanatory variables including GDP per capita, government expenditures per capita, government expenditures on primary expenditures per capita, both in USD or in \%, national democracy index, and primary teachers' salaries, was examined by multivariable linear models. In the case of a model with all independent variables, results show that all variables with the exception of teacher's salaries were statistically significant at least at 0.05 level $\left(R^{2}=0.741\right)$. This finding of weak or no dependence between teacher salaries and PISA scores is in contradiction with several previous studies, namely Akiba et al.
(2006), Carnoy et al. (2009), and Agasisti (2011; 2014) but in concord with findings of Gavurova et al. (2017). As teacher's salaries were not statistically significant, the variable was omitted in further models. While for the estimated linear model without teachers' salaries covering only OECD countries all independent variables were statistically significant at least at 0.05 level $\left(R^{2}=0.645\right)$, the same model estimated for nonOECD countries gives different results; the only statistically significant variables were the GDP per capita and the Democracy index. However, our results were limited by the fact that not all variables were available for all countries. Nevertheless, the presented multivariable models fitted the data very well.

Similarities among countries were examined by the complementary cluster analysis method. The division between OECD and non-OECD countries was found statistically significant at 0.01 level. When the countries were divided into three clusters, the following pattern emerged: for the countries with the highest PISA scores also high values of GDP per capita, expenditures on primary education per capita (in USD) and the Democracy index were typical. On the other hand, the countries with the lowest scores in PISA tests were characterized by low values of all independent variables including GDP per capita, expenditures on primary education per capita (both in \% of GDP and in USD), and the Democracy index.

All three used statistical tools were different, however together they provided complex insight into the problematics of economic and social variable influence on respective countries' PISA results. While basic descriptive statistics and variable correlation results suggested the use of multivariable models, data visualization indicated possible nonlinearity in some explanatory variables. Moreover, this nonlinearity showed the possibility of existence of the 'saturated level' of PISA - the maximum level that PISA score can obtain in real data (because maximum PISA scores are bound). Hence, while multivariable models studied joint effect of explanatory variables on PISA scores and results were more or less similar to already existed research, the Törnquist growth function estimations revealed optimal levels of two main economic variables - namely GDP per capita and government expenditures on primary education per capita - on obtaining of saturated levels of PISA scores. Moreover, multivariable 
models indicated that there are differences in results in different groups of countries (not necessarily groups of richer and poorer countries); and one-to one models showed that the level of main economic indicator - GDP - could be possibly compensated by higher expenditures on primary education. Hence, the next logical step was to find groups of countries and to determinate what was crucial in their obtained PISA results. The most interesting result is depicted in Fig. 3 - countries with relatively low levels of GDP but high government expenditure on primary education per student in percentage of GDP obtained above average PISA scores.

In general, all three used statistical tools helped to receive complex description of problematics of possible influence of economic and social factors on level of obtained knowledge of students measured by PISA scores. As for research limitations, unavailable data for some countries, especially the data on primary teachers' salaries, might contribute to weaker statistical relationships with respect to this variable. Also, PISA 2015 results were certainly influenced by other (not examined in this study because of unavailable data) factors, such as informal learning via the Internet, quality of school management, or cultural environment.

Further research may focus more on social factors; since economic factors play a significant role mainly in poorer countries. What lies behind differences in international tests of students from wealthy countries has to be still examined.

This paper was supported by the Ministry of Education, Youth and Sports, Czech Republic, within the Institutional Support for the Longterm Development of a Research Organization in 2018.

\section{References}

Afonso, A., \& Aubyn, M. S. (2005). Nonparametric Approaches to Education and Health Expenditure Efficiency in the OECD. Journal of Applied Economics, 8(2), 227-246. https://dx.doi.org/10.2139/ssrn.498383.

Afonso, A., \& Aubyn, M. S. (2006). Crosscountry efficiency of secondary education provision: a semi-parametric analysis with non-discretionary inputs. Economic Modeling,
23(3), 476-491. https://dx.doi.org/10.1016/j. econmod.2006.02.003.

Agasisti,T.(2011).Performancesandspending efficiency in higher education: A European comparison through non-parametric approaches. Education Economics, 19(2), 199-224. https://dx.doi.org/10.1080/09645290903094174.

Agasisti, T. (2014). The Efficiency of Public Spending on Education: an empirical comparison of EU countries. European Journal of Education, 49(4), 543-557. https://dx.doi. org/10.1111/ejed.12069.

Akiba, M., Chiu, Y.-L., Shimizu, K., \& Liang, G. (2012) Teacher salary and national achievement: A cross-national analysis of 30 countries. International Journal of Educational Research, 53, 171-181. https://dx.doi. org/10.1016/j.ijer.2012.03.007.

Aristovnik, A., \& Obadic, A. (2014). Measuring relative efficiency of secondary education in selected EU and OECD countries: the case of Sloveniaand Croatia. TechnologicalandEconomic Development of Economy, 20(3), 419-433. https://dx.doi.org/10.3846/20294913.2014.880085.

Aubyn, M. S., Pina, Á., Garcia, F., \& Pais, J. (2009). Study on the efficiency and effectiveness of public spending on tertiary education [Economics Papers, 390]. Brussels, European Committee. https://dx.doi.org/10.2765/30348.

Brunello, G., \& Rocco, L. (2013). The effect of migration on the school performance of natives: cross country evidence using PISA test scores. Economics of Education Review, 32, 234-246. https://dx.doi.org/10.1016/j. econedurev.2012.10.006.

Carnoy, M., Beteille, T., Brodziak, I., Loyalka, P., \& Luschei, T. (2009). Do Countries Paying Teachers Higher Relative Salaries Have Higher Student Mathematics Achievement? Teacher Education and Development Study in Mathematics (TEDS-M). Report for the International Association for the Evaluation of Educational Achievement (IEA).

Clements, B. (2002). How efficient is education spending in Europe? European Review of Economics and Finance, 1(1), 3-26.

Education at a Glance. (2016). Retrieved December 11, 2017, from http://www.oecd.org/ education/skills-beyond-school/education-at-aglance-2016-indicators.htm.

EIU. (2017). Economic Intelligence Unit. Retrieved December 11, 2017, from https://www.eiu.com/public/topical_report. aspx?campaignid=Democracylndex2016. 
Flores, I. (2017). Modelling efficiency in education: how are European countries spending their budgets and what relation between money and performance. Sociologia, Problemas e Práticas, 83, 157-170. Retrieved December 11, 2017, from http://journals. openedition.org/spp/2764.

French, J. J., French, A., \& Li, W.-X. (2015). The relationship among cultural dimensions, education expenditure, and PISA performance. International Journal of Educational Development, 42, 25-34. https://dx.doi.org/10.1016/j.jedudev.2015.02.010.

Gavurova, B., Kocisova, K., Belas, L., \& Krajcik, V. (2017). Relative efficiency of government expenditure on secondary education. Journal of International Studies, 10(2), 329-343. https://dx.doi. org/10.14254/2071-8330.2017/10-2/23.

Hanushek, E. A. (1986). The economics of schooling: production and efficiency in the public schools. Journal of Economic Literature, 24(3), 1141-1178.

Hanushek, E. A., \& Woessmann, L. (2011). The economics of international differences in educational achievement. In E. A. Hanushek, S. Machin, \& L. Woessmann (Eds.), Handbook of the Economics of Education (pp. 89-200). Amsterdam: North Holland.

Herrera, S., \& Pang, G. (2005). Efficiency of Public Spending in Developing Countries: An Efficiency Frontier Approach. Washington, D.C.: World Bank Publications. https://doi. org/10.1596/1813-9450-3645.

Kanungo, T., Mount, D. M., Netanyahu, N. S., Piatko, S. D., Silverman R., \& Wu, A. Y. (2002). An efficient k-means clustering algorithm: analysis and implementation. IEEE Transactions on Pattern Analysis and Machine Intelligence, 24(7), 881-892. https://dx.doi. org/10.1109/TPAMI.2002.1017616.

Kmenta, J. (1986). Elements of Econometrics (2nd ed.). New York: Macmillan.

Lockheed, M., \& Hanushek, E. A. (1994). Concepts of educational efficiency and effectiveness. [Human Resources Development and Operations Policy Working Papers, No. HRO 24]. Washington, DC: World Bank.

Lorcu, F., \& Acar Bolat, B. (2015). Comparison of secondary education PISA results in European member states and Turkey via DEA and SEM. Journal of WEI Business and Economics, 4(3), 7-17.

McKinsey \& Company. (2010). Klesající výsledky českého základního a stredního školství: fakta a řešení. Retrieved January 20, 2019, from https://www.mckinsey.com/ cz/ /media/McKinsey/Locations/Europe $\% 20$ and\%20Middle\%20East/Czech\%20Republic/ Our\%20work/McKinsey_pro_bono_skolstvi. ashx.

Nicoletti, C., \& Rabe, B. (2012). The effect of school resources on test scores in England. Research paper: Institute for Economic and Social Research. Retrieved December 11, 2017, from https://www.iser.essex.ac.uk/ publications/working-papers/iser/2012-13.pdf.

PISA 2015. (2016). Results in Focus. Retrieved December 11, 2017, from https:// www.oecd.org/pisa/pisa-2015-results-in-focus. pdf.

Rindermann, H., \& Ceci, S. J. (2009). Educational policy and country outcomes in international cognitive competence studies. Perspectives on Psychological Science, 4(6), 551-577. https://dx.doi.org/10.1111/j.17456924.2009.01165.x.

Sutherland, D., Price, R., \& Gonand, F. (2009). Improving public spending efficiency in primary and secondary education. OECD Journal: Economic Studies, 1, 1-30. https://dx.doi.org/10.1787/19952856.

Waldfogel, J., \& Zhai, F. (2008). Effects of Public Preschool Expenditures on the Test Scores of $4^{\text {th }}$ Graders: Evidence from TIMSS. Educational Research and Evaluation, 14(1), 9-28. https://dx.doi. org/10.1080/13803610801896372.

World Bank. (2017). Retrieved December 11, 2017, from https://data.worldbank.org/.

Wolff, E. N. (2015). Educational expenditures and student performance among 


\section{Economics}

OECD countries. Structural Change and Economic Dynamics, 33, 37-57. https://dx.doi. org/10.1016/j.strueco.2015.02.003.

Yorulmaz, Y. I., Colak, I., \& Ekinci, C. E. (2017). An evaluation of PISA 2015 achievements of OECD countries within income distribution and education expenditures. Turkish Journal of Education, 6(4), 169-185. https://dx.doi.org/10.19128/turje.329755.
Mgr. Jiří Mazurek, Ph.D. Silesian University in Opava School of Business Administration in Karvina Department of Informatics and Mathematics Czech Republic mazurek@opf.slu.cz

Ing. Elena Mielcová, Ph.D. Silesian University in Opava School of Business Administration in Karvina Department of Informatics and Mathematics Czech Republic mielcova@opf.slu.cz 
Economics

\section{Appendix A: Results of cluster analysis - selected models (Part 1)}

\begin{tabular}{|c|c|c|c|c|}
\hline COUNTRYIVARIABLE & $\begin{array}{l}\text { MODEL } 1 \\
2 \text { clusters }\end{array}$ & $\begin{array}{l}\text { MODEL } 2 \\
4 \text { clusters }\end{array}$ & $\begin{array}{l}\text { MODEL } 3 \\
3 \text { clusters }\end{array}$ & $\begin{array}{l}\text { MODEL } 4 \\
3 \text { clusters }\end{array}$ \\
\hline (column 1) & (2) & (3) & (4) & (5) \\
\hline PISA & $x$ & $x$ & $\checkmark$ & $\checkmark$ \\
\hline MATH & $\checkmark$ & $\checkmark$ & $x$ & $x$ \\
\hline SCIENCE & $\checkmark$ & $\checkmark$ & $x$ & $x$ \\
\hline READING & $\checkmark$ & $\checkmark$ & $x$ & $x$ \\
\hline GDP & $\checkmark$ & $\checkmark$ & $\checkmark$ & $\checkmark$ \\
\hline PEREXP & $\checkmark$ & $x$ & $\checkmark$ & $\checkmark$ \\
\hline EXPEND & $\checkmark$ & $x$ & $\checkmark$ & $\checkmark$ \\
\hline DEM & $\checkmark$ & $\checkmark$ & $\checkmark$ & $x$ \\
\hline SALARY & $x$ & $x$ & $x$ & $x$ \\
\hline \multicolumn{5}{|l|}{ Country } \\
\hline Albania & . & . & . & . \\
\hline Algreria & . & 1 & . & . \\
\hline Australia & 1 & 2 & 2 & 2 \\
\hline Austria & 1 & 2 & 2 & 2 \\
\hline Belgium & 1 & 2 & 2 & 2 \\
\hline Brazil & 2 & 1 & 3 & 3 \\
\hline Bulgaria & 2 & 4 & 3 & 1 \\
\hline Canada & . & 2 & . & . \\
\hline Colombia & 2 & 1 & 3 & 3 \\
\hline Costa Rica & 2 & 4 & 3 & 1 \\
\hline Croatia & . & 4 & . & . \\
\hline Cyprus & 1 & 4 & 1 & 1 \\
\hline Czech Rep. & 1 & 3 & 3 & 3 \\
\hline Denmark & 1 & 2 & 2 & 2 \\
\hline Dominican Rep. & 2 & 1 & 3 & 3 \\
\hline Estonia & 1 & 3 & 1 & 1 \\
\hline Finland & 1 & 2 & 2 & 2 \\
\hline France & 1 & 2 & 2 & 2 \\
\hline Georgia & 2 & 1 & 3 & 3 \\
\hline Germany & 1 & 2 & 2 & 2 \\
\hline Greece & . & 4 & . & . \\
\hline Hong Kong & 1 & 3 & 2 & 2 \\
\hline
\end{tabular}




\section{Appendix A: Results of cluster analysis - selected models (Part 2)}

\begin{tabular}{|c|c|c|c|c|}
\hline COUNTRY/VARIABLE & $\begin{array}{l}\text { MODEL } 1 \\
2 \text { clusters } \\
\end{array}$ & $\begin{array}{l}\text { MODEL } 2 \\
4 \text { clusters } \\
\end{array}$ & $\begin{array}{l}\text { MODEL } 3 \\
3 \text { clusters } \\
\end{array}$ & $\begin{array}{l}\text { MODEL } 4 \\
3 \text { clusters } \\
\end{array}$ \\
\hline Hungary & 2 & 4 & 1 & 1 \\
\hline Chile & 2 & 4 & 3 & 3 \\
\hline China & & 3 & . & . \\
\hline Iceland & 1 & 2 & 2 & 2 \\
\hline Indonesia & 2 & 1 & 3 & 3 \\
\hline Ireland & 1 & 2 & 2 & 2 \\
\hline Israel & 1 & 4 & 1 & 1 \\
\hline Italy & 1 & 2 & 1 & 2 \\
\hline Japan & 1 & 2 & 2 & 2 \\
\hline Jordan & 2 & 1 & 3 & 3 \\
\hline Kazakhstan & . & 1 & . & . \\
\hline Kosovo & . & . & . & . \\
\hline Latvia & 1 & 3 & 1 & 1 \\
\hline Lebanon & . & 1 & . & . \\
\hline Lithuania & 2 & 4 & 3 & 1 \\
\hline Luxembourg & 1 & 2 & 2 & 2 \\
\hline Macau & . & . & . & . \\
\hline Macedonia & . & 1 & . & . \\
\hline Malaysia & 2 & 4 & 3 & 3 \\
\hline Malta & 1 & 4 & 1 & 1 \\
\hline Mexico & 2 & 1 & 3 & 3 \\
\hline Moldova & 2 & 1 & 1 & 1 \\
\hline Montenegro & . & 1 & . & . \\
\hline Netherlands & 1 & 2 & 2 & 2 \\
\hline New Zealand & 1 & 2 & 2 & 2 \\
\hline Norway & 1 & 2 & 2 & 2 \\
\hline Peru & 2 & 1 & 3 & 3 \\
\hline Poland & 1 & 3 & 1 & 1 \\
\hline Portugal & 1 & 3 & 1 & 1 \\
\hline Qatar & 2 & 1 & 3 & 2 \\
\hline Romania & 2 & 4 & 3 & 3 \\
\hline Russia & . & 3 & . & . \\
\hline Singapore & 1 & 3 & 2 & 2 \\
\hline
\end{tabular}




\section{Economics}

Appendix A: Results of cluster analysis - selected models (Part 3)

\begin{tabular}{|c|c|c|c|c|}
\hline COUNTRY/VARIABLE & $\begin{array}{l}\text { MODEL } 1 \\
2 \text { clusters }\end{array}$ & $\begin{array}{l}\text { MODEL } 2 \\
4 \text { clusters }\end{array}$ & $\begin{array}{l}\text { MODEL } 3 \\
3 \text { clusters }\end{array}$ & $\begin{array}{l}\text { MODEL } 4 \\
3 \text { clusters }\end{array}$ \\
\hline Slovakia & 2 & 4 & 3 & 1 \\
\hline Slovenia & 1 & 3 & 1 & 1 \\
\hline South Korea & 1 & 3 & 1 & 1 \\
\hline Spain & 1 & 2 & 1 & 1 \\
\hline Sweden & 1 & 2 & 2 & 2 \\
\hline Switzerland & 1 & 2 & 2 & 2 \\
\hline Taiwan & . & . & . & . \\
\hline Thailand & 2 & 1 & 3 & 1 \\
\hline Trinidad and Tobago & 2 & 4 & 3 & 3 \\
\hline Tunisia & 2 & 1 & 3 & 3 \\
\hline Turkey & 2 & 1 & 3 & 3 \\
\hline UK & 1 & 2 & 2 & 2 \\
\hline United Arab Emirates & . & 1 & . & . \\
\hline United States & 1 & 2 & 2 & 2 \\
\hline Uruguay & 2 & 4 & 3 & 3 \\
\hline Vietnam & . & . & . & 1 \\
\hline
\end{tabular}




\section{Abstract}

\section{ON THE RELATIONSHIP BETWEEN SELECTED SOCIO-ECONOMIC INDICATORS AND STUDENT PERFORMANCES IN THE PISA 2015 STUDY}

\section{Jiří Mazurek, Elena Mielcová}

The main aim of this paper was to examine the relationship between the PISA (Programme for International Student Assessment) international study results of 15 and 16 years-old pupils from 2015 and a set of socio-economic indicators (on a national level) such as governments'expenditures on primary education, gross domestic product per capita, the Democracy index compiled by the Economist Intelligence Unit, or primary teachers' salaries. The study covered 71 countries or territories, including 34 OECD countries and their 37 non-OECD counterparts. The methods included multivariate linear models, models based on Törnquist functions, and cluster analysis. The main result of the study is that there exists a threshold in terms of GDP per capita and government expenditures on primary education per capita. Above the threshold, the higher GDP per capita or expenditures do not translate into the higher PISA scores. However, below this threshold, the opposite is true. Therefore, poorer and mainly non-OECD countries may achieve better student performances in PISA tests by increasing expenditures on primary education, while for student performances of the wealthy and mainly OECD countries expenditures are not a statistically significant factor. The division between OECD and non-OECD countries was also confirmed to be statistically significant by cluster analysis method. In addition, from linear multivariate models it was found that PISA scores were statistically significantly (and positively) related to the national GDP per capita, governments' expenditures on primary education, and the Democracy index, while the influence of primary teachers' salaries on PISA scores was found statistically insignificant.

Key Words: Education, PISA 2015, primary education, expenditures on education.

JEL Classification: I20.

DOI: 10.15240/tul/001/2019-2-002 